\title{
Penentuan Dosen Berprestasi Menggunakan Metode Analytical Network Process
}

Determination of Lecturer Achievement Using Method Analytical Network Process

\author{
${ }^{1}$ Karnita Afnisari, ${ }^{2}$ Indah Purnamasari \\ ${ }^{1}$ Manajemen Informatika, Akademik Manajemen Informatika dan Komputer Bina Sarana \\ Informatika, ${ }^{2}$ Sistem Informasi, Sekolah Tinggi Manajemen Informatika dan Komputer Nusa \\ Mandiri \\ ${ }^{1,2}$ Jakarta, Indonesia \\ Email : ${ }^{1}$ karnita04@gmail.com, ${ }^{2}$ indah.ihi@ nusamandiri.ac.id
}

Abstrak-Pendidikan tinggi adalah subsistem yang mencakup program diploma, sarjana, master, spesialis dan doktor yang diselenggarakan oleh perguruan tinggi baik akademi, sekolah tinggi maupun universitas. Perguruan tinggi wajib memberikan pendidikan, penelitian, dan pengabdian kepada masyarakat. Salah satu elemen dalam administrasi pendidikan tinggi adalah dosen.Dosen adalah tenaga akademik yang bertanggung jawab untuk merencanakan dan melaksanakan proses pembelajaran, menilai hasil pembelajaran, melakukan pembinaan dan pelatihan, dan melakukan penelitian dan pengabdian kepada masyarakat. Berdasarkan Undang-Undang Republik Indonesia Nomor 14 Tahun 2005 tentang Guru dan Dosen, Pasal 51 Ayat (1) Butir b, profesor berhak atas promosi dan penghargaan sesuai dengan prestasi akademik.Penelitian ini menggunakan metode Analytical Network Process (ANP). Dengan menggunakan perangkat lunak Superdecision. Krite ria yang digunakan dalam penelitian ini adalah pengajaran, penelitian dan pengabdian mas yarakat.Hasil dari penelitian ini adalah hubungan antara pengajaran, penelitian dan pengabdian masyarakat terkait dengan fakultas luar biasa dalam pemilihan di mana persentase dalam memilih kine rja mengajar dosen yang luar biasa pada tingkat pertama $=22 \%$, Kepribadian $=18 \%$, Pengajaran $=21 \%$, Penelitian $=21 \%$, Komunitas pengabdian $=16 \%$.

Kata Kunci-Dosen Luar Biasa, AnalyticalNetwork Process (ANP), SuperDecision

Abstract-Higher education is a subsystem that includes a program of national education diploma, bachelor, masters, specialist and doctoral degrees held by college both academy, high school and university. College are obliged to provide education, research and community service. One element in the administration of higher education are the lecturer. Lecturers are academic personnel responsible for planning and executing the learning process, assess learning outcomes, conduct coaching and training, and conduct research 
INTENSIF, Vol.2 No.2 August 2018

ISSN: 2580-409X (Print) / 2549-6824 (Online)

Website: http://ojs.unpkediri.ac.id/index.php/intens if

and community service. Based on the Law of the Republic of Indonesia Number 14 Year 2005 on Teachers and Lecturers, Article 51 Paragraph (1) Item b, the professor is entitled to promotions and awards in accordance with academic performance. This study used the ANP method (Analytical Network Process). By using Superdecision software. The criteria used in this study is the teaching, research and community service. The results of this research is the relationship between teaching, research and community service related to the outstanding faculty in the election where the percentages in selecting outstanding faculty teaching performance at the first level $=22 \%$, Personality $=18 \%$, Teaching $=21 \%$, $21 \%$ Research $=$, Devotion community $=16 \%$

Keywords—outstanding lecturers, ANP (Analytical Network Process), SuperDecision

\section{PENDAHULUAN}

Lembaga Pendidikan Tinggi di Indonesia merupakan subsistem pendidikan nasional yang mencakup program diploma, sarjana, magister, spesialis dan doktor yang dise lenggarakan oleh perguruan tinggi baik akademi, sekolah tinggi maupun universitas. Perguruan tinggi wajib menyelenggarakan pendidikan, penelitian dan pengabdian kepada masyarakat. Salah satu elemen dalam perguruan tinggi adalah dosen. Dosen merupakan tenaga akademik yang bertugas merencanakan dan melaksanakan proses pembelajaran, menilai hasil pembelajaran, melakukan pembimbingan dan pelatihan, serta melakukan penelitian serta pengabdian kepada masyarakat.

Berdasarkan Undang-undang Republik Indonesia No 14 tahun 2005 tentang Guru dan Dosen, Pasal 51 Ayat (1) Butir b, bahwa dosen berhak mendapatkan promosi dan penghargaan sesuai dengan kinerja akademiknya. Merujuk pada Undang undang di atas, maka pemberian penghargaan diberikan kepada dosen yang memiliki prestasi membanggakan oleh perguruan tingginya dalam bidang tridharma perguruan tinggi yaitu pendidikan, penelitian dan pengabdian kepada masyarakat. Pemberian penghargaan akan mendorong dosen untuk berprestasi secara lebih baik lagi sehingga diharapkan dapat mendorong tercapainya tujuan pengembangan sistem pendidikan tinggi khususnya, dan pembangunan nasional.

Pemilihan dosen berprestasi dalam suatu lembaga pendidikan sangat sulit, karena banyaknya dosen yang memungkinkan mempunyai syarat-syarat dalam menentukan dosen berprestasi. Banyaknya kriteria yang digunakan ini menjadi permasalahan tersendiri, sehingga memerlukan penyelesaian, sebagai pendukung keputusan dengan multikriteria [1] untuk 
INTENSIF, Vol.2 No.2 August 2018

ISSN: 2580-409X (Print) / 2549-6824 (Online)

Website: http://ojs.unpkediri.ac.id/index.php/intensif

mempermudah suatu lembaga pendidikan dalam menentukan dosen yang benar-benar berprestasi berdasarkan faktor-faktor yang ada.

Dalam menentukan sistem penunjang keputusan, banyak metode yang dapat digunakan dalam memenuhi kebutuhan pengambilan keputusan, namun pada penelitian kali ini penulis memilih analytic network process (ANP), sebagai model yang digunakan untuk pengambilan keputusan. Pemilihan metode ini didasarkan kepada ketepatan dalam memilih dosen yang mampu mengakomodasikan ketergantungan antar kriteria dan umpan balik antar label kriteria.

\section{Sistem Pendukung Keputusan}

Sistem pendukung keputusan pertama kali dikemukakan awal tahun 1970-an oleh Michael S.Scott Morton dengan istilah Management Decision System (Sistem Pendukung Keputusan Manajemen). Sistem pendukung Keputusan adalah seperangkat sistem yang mampu memecahkan masalah secara efisien dan efektif [2]. Sistem pendukung keputusan berbasis komputer (Computer Based Decision Support System) merupakan sistem yang berbasis komputer yang dirancang untuk meningkatkan efektifitas pengambil keputusan dalam memecahkan masalah yang bersifat semi struktur dan terstruktur[3]. Karakteristik dan kemampuan ideal dari suatu Decision Support System (DSS) ditunjukkan pada gambar 1.

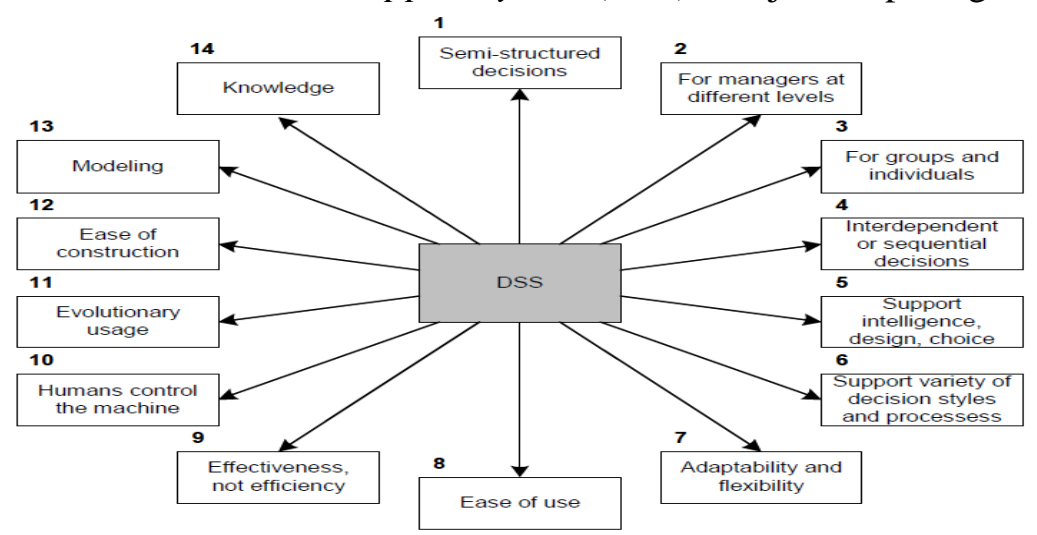

Gambar 1. KARAKTERISTIK DAN KEM AMPUAN IDEAL DARI SUATU DSS

\section{Analytic Network Process (ANP)}

The Analytic Network Process (ANP) adalah generalisasi dari Analytic Proses Hirarki (AHP). Struktur dasar adalah jaringan pengaruh cluster dan node yang terkandung dalam cluster [4].

Analytical Network Process (ANP) merupakan kerangka kerja paling komprehensif dalam enganalisis pengambilan keputusan. Kelebihan metode ANP adalah mampu memperbaiki kelemahan AHP berupa kemampuan mengakomodasi keterkaitan antar kriteria [5]. 
INTENSIF, Vol.2 No.2 August 2018

ISSN: 2580-409X (Print) / 2549-6824 (Online)

Website: http://ojs.unpkediri.ac.id/index.php/intensif

Analytical Network Process (ANP) adalah teori umum yang digunakan untuk menurunkan rasio prioritas komposit dari skala rasio individu yang mencerminkan pengukuran relatif dari pengaruh elemen-elemen yang saling berinteraksi berkenaan dengan kriteria kontrol.

ANP memiliki beberapa kelebihan jika dibandingkan dengan AHP. Gambar 2. berikut ini menunjukkan perbandingan antara hirarki linier yang digunakan oleh metode ANP dan jaringan feedback yang digunakan oleh metode AHP.

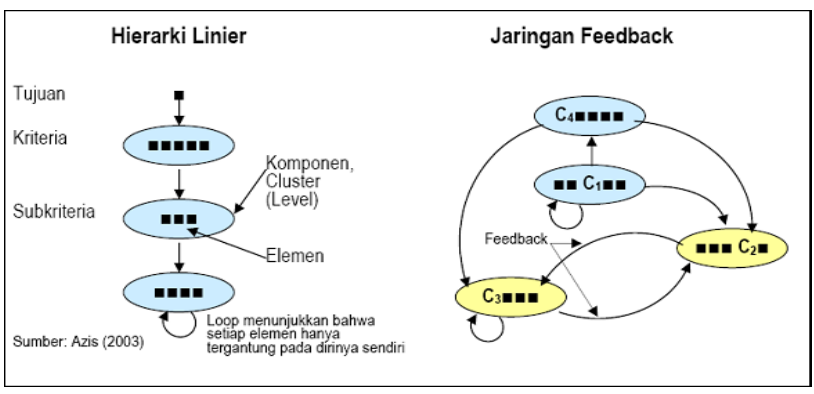

Gambar 2. PERBANDINGAN HIERARKI LINIER DAN JARINGAN FEEDBACK

\section{METODE PENELITIAN}

Jenis penelitian ini termasuk ke dalam jenis penelitian deskriptif yaitu penelitian yang melukiskan keadaan yang sebenarnya guna memperoleh fakta yang akan diolah menjadi data, dan selanjutkan akan dijadikan kesimpulan, yang dibangun dengan pendekatan Analytical Network Process (ANP). Setelah itu diuji dengan menggunakan salah satu perangkat lunak Super Decisions versi 2.0.8. Model pengambilan keputusan dengan menggunakan ANP ditunjukkan pada gambar 3 berikut ini.

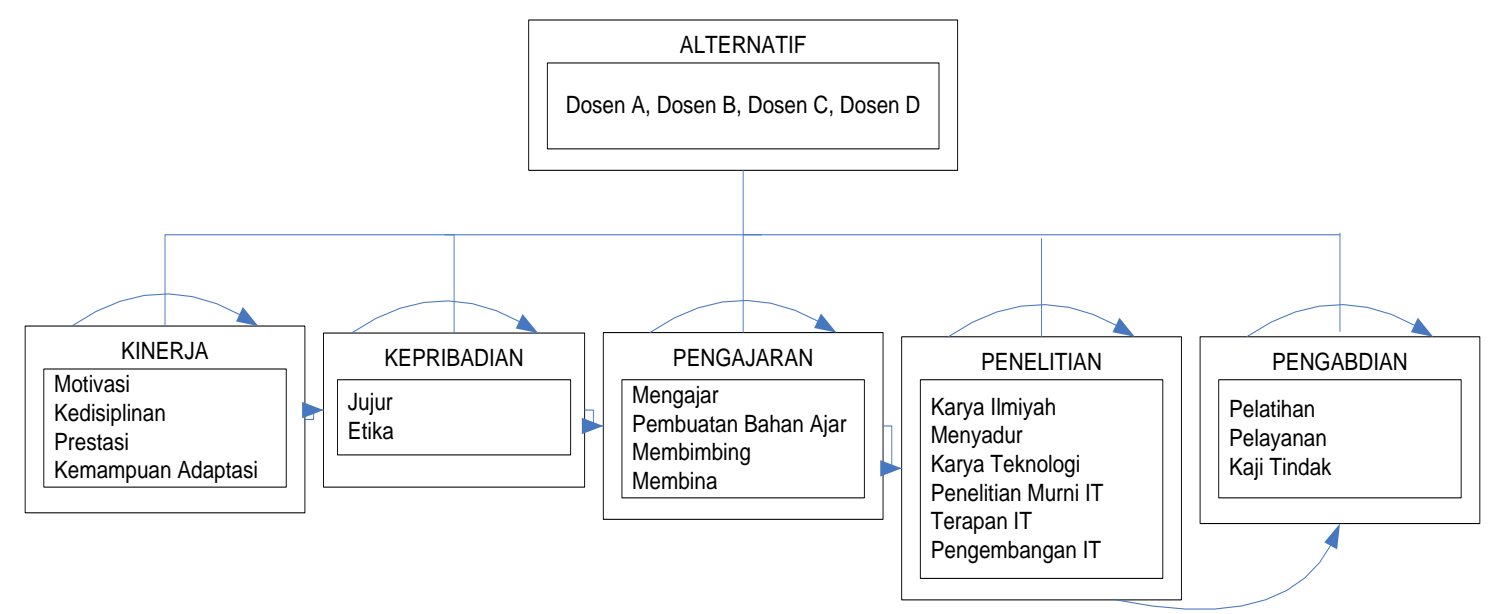

Gambar 3. MODEL ANP DALAM MENENTUKAN DOSEN BERPRESTASI 
INTENSIF, Vol.2 No.2 August 2018

ISSN: 2580-409X (Print) / 2549-6824 (Online)

Website: http://ojs.unpkediri.ac.id/index.php/intens if

Secara umum langkah-langkah yang harus dilakukan dalam menggunakan ANP adalah:

1. Mendefinisikan masalah dan menentukan kriteria solusi yang diinginkan.

2. Menentukan pembobotan komponen dari sudut pandang manajerial.

3. Membuat matriks perbandingan berpasangan yang menggambarkan kontribusi atau pengaruh setiap elemen atas setiap kriteria. Perbandingan dilakukan berdasarkan penilaian dari pengambil keputusan dengan menilai tingkat kepentingan suatu elemen.

4. Setelah mengumpulkan semua data perbandingan berpasangan dan memasukkan nilai-nilai kebalikannya serta nilai satu di sepanjang diagonal utama, prioritas masing-masing kriteria dicari dan konsistensi diuji.

5. Menentukan eigenvector dari matriks yang telah dibuat pada langkah ketiga.

6. Mengulangi langkah 3, 4, dan 5 untuk semua kriteria.

7. Membuat unweighted super matrix dengan cara memasukkan semua eigen vector yang telah dihitung pada langkah 5 ke dalam sebuah super matriks.

8. Membuat weighted super matrix dengan cara melakukan perkalian setiap isi unweighted supermatrix terhadap matriks perbandingan kriteria (cluster matrix).

9. Membuat limiting supermatrix dengan cara memangkatkan super matriks secara terus menerus hingga angka disetiap kolom dalam satu baris sama besar, setelah itu lakukan normalisasi terhadap limiting supermatrix.

10. Ambil nilai dari alternatif yang dibandingkan kemudian dinormalisasi untuk mengetahui hasil akhir perhitungan.

11. Memeriksa konsistensi, rasio konsistensi tersebut harus 10 persen atau kurang. Jika nilainya lebih dari 10\%, maka penilaian data keputusan harus diperbaiki

Sistem hirarki yang digunakan pada etode ANP yaitu membandingkan dalam bentuk berpasangan seluruh untuk setiap sub sistem hirarki kemudian ditransformasikan ke dalam bentuk matriks $\mathrm{n} \times \mathrm{n}$ seperti pada gambar 4 .

\begin{tabular}{|c|ccccc|}
\hline $\mathrm{A}$ & $\mathrm{B}_{1}$ & $\mathrm{~B}_{2}$ & $\mathrm{~B}_{3}$ & - & $\mathrm{B}_{\mathrm{n}}$ \\
\hline $\mathrm{B}_{1}$ & $\mathrm{~b}_{11}$ & $\mathrm{~b}_{12}$ & $\mathrm{~b}_{13}$ & -- & $\mathrm{b}_{1 \mathrm{n}}$ \\
$\mathrm{B}_{2}$ & $\mathrm{~b}_{21}$ & $\mathrm{~b}_{22}$ & $\mathrm{~b}_{23}$ & - & $\mathrm{b}_{2 \mathrm{n}}$ \\
$\mathrm{B}_{3}$ & $\mathrm{~b}_{31}$ & $\mathrm{~b}_{32}$ & $\mathrm{~b}_{33}$ & -- & $\mathrm{b}_{3 \mathrm{n}}$ \\
-- & - & - & - & - & - \\
$\mathrm{B}_{\mathrm{n}}$ & $\mathrm{b}_{\mathrm{n} 1}$ & $\mathrm{~b}_{\mathrm{n} 2}$ & $\mathrm{~b}_{\mathrm{n} 3}$ & - & $\mathrm{b}_{\mathrm{nn}}$ \\
\hline
\end{tabular}

Gambar 4. MATRIKS PERBANDINGAN BERPASANGAN 
ISSN: 2580-409X (Print) / 2549-6824 (Online)

Website: http://ojs.unpkediri.ac.id/index.php/intens if

Rumus perhitungan ANP, dapat dilihat pada persamaan (1).

$$
\begin{gathered}
\lim _{M \rightarrow \infty} \frac{1}{M} \sum_{k=1}^{M} \frac{\sum_{j=1}^{n} a_{i j}{ }_{i=1}^{n} \sum_{j=1}^{n} a_{i j}{ }^{k}}{\mathrm{CI}}=(\lambda \max -\mathrm{n}) /(\mathrm{n}-1) \\
\mathrm{CR}=\mathrm{CI} / \mathrm{RI}
\end{gathered}
$$

Keterangan : $\quad \mathrm{CI}=$ Consistency Index

$$
\begin{aligned}
& \lambda=\text { Nilai eigen } \\
& \mathrm{n}=\text { jumlah elemen } \\
& \mathrm{CR}=\text { Consistency Ratio } \\
& \mathrm{RI}=\text { Random Index }
\end{aligned}
$$

Metode Pemilihan responden dalam ANP dilakukan berdasarkan teknik purposive sampling dengan pertimbangan bahwa responden adalah pelaku baik individu atau lembaga yang dianggap mengerti akan permasalahan yang terjadi dan merupakan bagian dari para pengambil keputusan untuk penilaian ini. Dalam hal ini responden yang dipilih adalah para pengambil keputusan yang biasa menilai Dosen dan mengerti dengan kriteria yang ada, dalam kampus tersebut ini tim penilai adalah Pembantu Ketua (PUKET), Ketua Jurusan Teknik Informatika (Kaprodi TI) serta Kepala Divsi Sumber Daya Manusia (Kadiv SDM), Kepala Divisi Pusat Pengendali Mutu, Kepala lembaga pengabdian masyarakat, Kepala divisi penelitian

Dalam penyusunan penelitian ini menggunakan kuisioner untuk mendapatkan informasi data yang akan digunakan untuk perhitungan. Dengan menggunakan kriteria yang ada pada perusahaan maka dibuat kuisioner untuk menentukan prioritas dalam menentukan dosen yang berhak mendapatkan prestasi dengan ketentuan ANP. Adapun ketentuannya yaitu kriteria yang telah ditentukan terdiri dari kriteria utama dan faktor-faktor dalam kriteria, juga ditambahkan alternatif sebagai sampel perbandingan. Persyaratan Dosen Berprestasi adalah yang memiliki Karya Prestasi Unggul dalam bidang Pendidikan, Penelitian dan Pengajaran [6]. Dalam proses ini disertakan kinerja, kepribadian, pengajaran, penelitian, dan pengabdian yang ditunjukkan pada tabel 1. 
INTENSIF, Vol.2 No.2 August 2018

ISSN: 2580-409X (Print) / 2549-6824 (Online)

Website: http://ojs.unpkediri.ac.id/index.php/intens if

Tabel 1. KRITERIA DAN FAKTOR

\begin{tabular}{|c|c|c|}
\hline No & Kriteria & Faktor dalam Krite ria \\
\hline \multirow[t]{4}{*}{1} & Kinerja & Motivasi \\
\hline & & Kedisiplinan \\
\hline & & Prestasi \\
\hline & & Kemampuan Adaptasi \\
\hline \multirow[t]{2}{*}{2} & Kepribadian & Jujur \\
\hline & & Etika \\
\hline \multirow[t]{4}{*}{3} & Pengajaran & Mengajar \\
\hline & & Pembuatan Bahan Ajar \\
\hline & & Membimbing \\
\hline & & Membina \\
\hline \multirow[t]{6}{*}{4} & Penelitan & Karya Ilmiyah \\
\hline & & Menyadur \\
\hline & & Karya Teknologi \\
\hline & & Penelitian Murni IT \\
\hline & & Terapan IT \\
\hline & & Pengembangan IT \\
\hline \multirow[t]{3}{*}{5} & Pengabdian & Pelatihan \\
\hline & & Pelayanan \\
\hline & & Kaji Tindak \\
\hline
\end{tabular}

Data yang telah dikumpulkan dapat dihitung dengan metode supermatrik sehingga bisa ditentukan model hirarki dari setiap kriteria atau bisa disebut juga sebagai Cluster.

Perbandingan skala penilaian verbal dan skala penilaian numerik ditunjukkan pada tabel 2 berikut ini. 
INTENSIF, Vol.2 No.2 August 2018

ISSN: 2580-409X (Print) / 2549-6824 (Online)

Website: http://ojs.unpkediri.ac.id/index.php/intens if

Tabel 2. Perbandingan Skala Penilaian Verbal Dan Skala NumeriK

\begin{tabular}{ccc}
\hline $\begin{array}{c}\text { Tingkat } \\
\text { Ke pentingan }\end{array}$ & Definisi & Keterangan \\
\hline 1 & Sama penting & kedua elemen mempunyai pengaruh yang sama \\
\hline 3 & $\begin{array}{c}\text { Sedikit lebih } \\
\text { penting }\end{array}$ & $\begin{array}{c}\text { pengalaman dan penilaian sedikit memihak satu } \\
\text { elemen dibandingkan pasangannya }\end{array}$ \\
\hline 5 & Lebih penting & $\begin{array}{c}\text { pengalaman dan penilaian dengan kuat memihak } \\
\text { satu elemen dibandingkan pasangannya }\end{array}$ \\
\hline 7 & Sangat & satu elemen sangat disukai dan secara praktis \\
penting & dominasinya terlihat \\
\hline 9 & Mutlak sangat & satu elemen terbukti mutlak lebih disukai \\
& penting & dibandingkan pasanyannya \\
\hline $2,4,6,8$ & Nilai tengah & ketika diperlukan sebuah kompromi \\
\hline Kebalikan & $\mathrm{a}_{\mathrm{ij}}=1 / \mathrm{a}_{\mathrm{ij}}$ & \\
\hline
\end{tabular}

\section{HASIL PENELITIAN}

Berdasarkan hasil penelitian faktor-faktor yang mempengaruhi dosen berprestasi dalam meningkatkan mutu pembelajaran di dalam Kampus UNISMA Bekasi, Responden yang diberikan kuesioner sebanyak enam yaitu Pembantu Ketua (PUKET), Ketua Jurusan Teknik Informatika (Kaprodi TI), Kepala Divsi Sumber Daya Manusia (Kadiv SDM), Kepala Divisi Pusat Pengendali Mutu, Kepala lembaga pengabdian masyarakat, Kepala divisi pene litian, masing-masing kuesioner terdiri atas empat dosen, Kuesioner tersebut dibagikan secara langsung ke pada responden Dengan mengisi kuesioner

Berdasarkan hasil dari perbandingan diantara alternatif dalam kriteria yang ada maka didapatkan sistem pendukung keputusan dalam menentukan dosen berprestasi yang tertera pada gambar 5 dibawah ini 


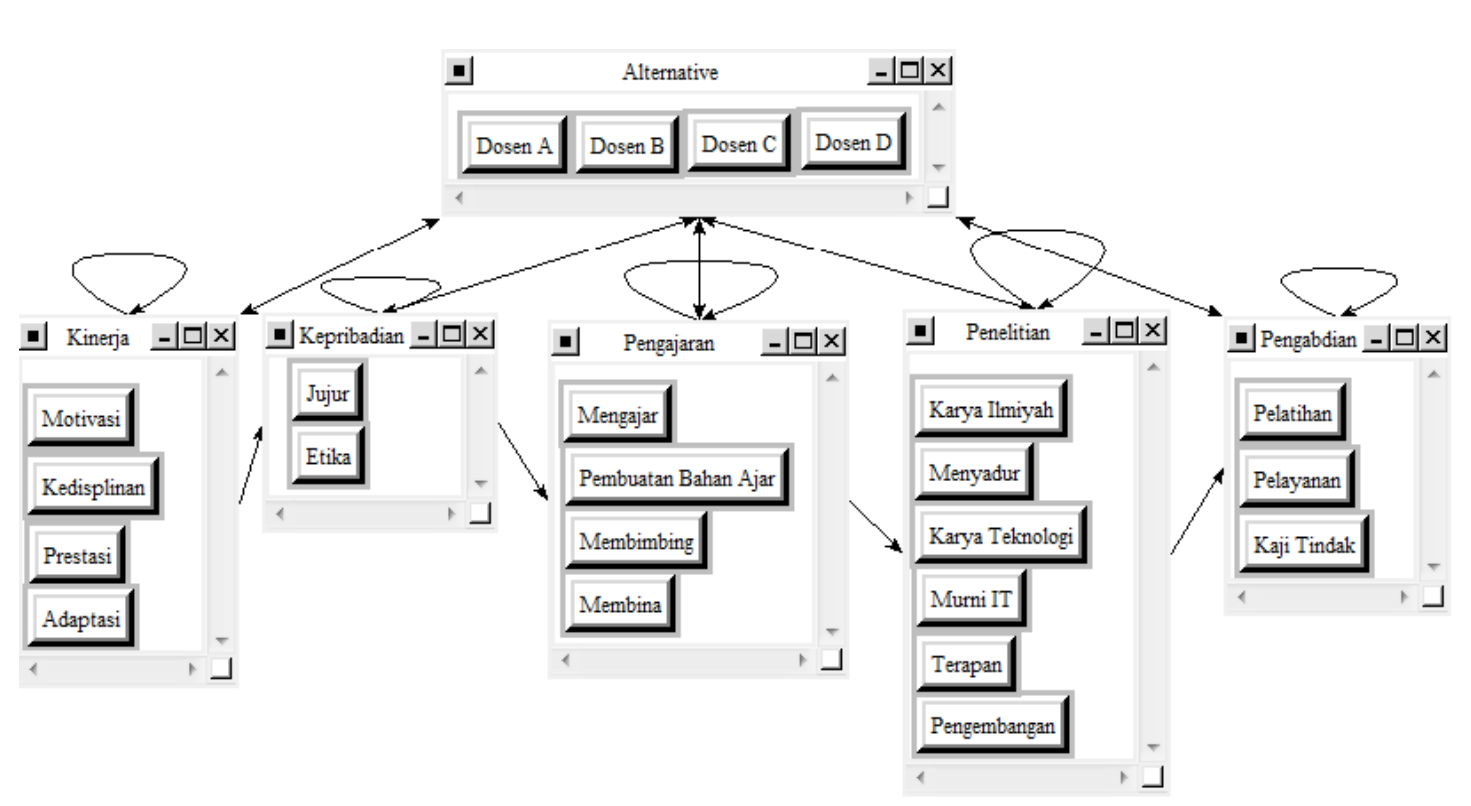

Gambar 5. MODEL DALAM MENENTUKAN DOSEN BERPRESTASI

Berdasarkan hasil penelitian yang diolah oleh software superdicision dari semua cluster maka didapatkan prioritas pada gambar 6 sebagai berikut :

\begin{tabular}{|c|c|c|c|c|c|}
\hline \multicolumn{6}{|c|}{\begin{tabular}{|l|l|l|l|}
2 Super Decisions Main Window: Db.mod: formulaic: Priorities & {[} & $x^{2}$ \\
\end{tabular}} \\
\hline \multicolumn{6}{|c|}{\begin{tabular}{|l|} 
Here are the priorities. \\
\end{tabular}} \\
\hline Icon & Name & & Ialized by Cluster & Limiting & - \\
\hline No Icon & Dosen A & $\Gamma$ & 0.25934 & 0.120850 & \\
\hline No Icon & Dosen B & Г & 0.24973 & 0.116374 & \\
\hline No Icon & Dosen C & $\Gamma$ & 0.24279 & 0.113140 & \\
\hline No Icon & Dosen D & $\Gamma$ & 0.24814 & 0.115630 & \\
\hline No Icon & Etika & Г & 0.50000 & 0.043935 & \\
\hline No Icon & Jujur & $\Gamma$ & 0.50000 & 0.043935 & \\
\hline No Icon & Adaptasi & $\Gamma$ & 0.18828 & 0.022572 & \\
\hline No Icon & Kedisplinan & Г & 0.30988 & 0.037151 & \\
\hline No Icon & Motivasi & $\Gamma$ & 0.23769 & 0.028496 & \\
\hline No Icon & Prestasi & Г & 0.26415 & 0.031668 & $\equiv$ \\
\hline No Icon & Karya Ilmiyah & Г & 0.19059 & 0.019990 & \\
\hline No Icon & Karya Teknologi & $\Gamma$ & 0.19177 & 0.020114 & \\
\hline No Icon & Menyadur & Г & 0.15592 & 0.016354 & \\
\hline No Icon & Murni IT & $\Gamma$ & 0.18572 & 0.019479 & \\
\hline No Icon & Pengembangan & Г & 0.13607 & 0.014272 & \\
\hline No Icon & Terapan & Г & 0.13992 & 0.014676 & \\
\hline No Icon & Kaji Tindak & Г & 0.26678 & 0.027804 & \\
\hline No Icon & Pelatihan & Г & 0.43337 & 0.045166 & \\
\hline No Icon & Pelayanan & Г & 0.29985 & 0.031251 & \\
\hline No Icon & Membimbing & Г & 0.23180 & 0.027154 & \\
\hline No Icon & Membina & Г & 0.21062 & 0.024673 & - \\
\hline \begin{tabular}{l|l} 
Okay & C
\end{tabular} & opy Values & & & & \\
\hline
\end{tabular}

Gambar 6. HASIL PENELITIAN PRIORITAS DOSEN BERPRESTASI

Berdasarkan prioritas diatas maka untuk kriteria kinerja yang prioritas paling utama adalah kedisiplinan yang berperan dalam menentukan dosen berprestasi, untuk kriteria kepribadian adalah jujur, untuk kriteria pengajaran adalah mengajar, untuk kriteria penelitian 
INTENSIF, Vol.2 No.2 August 2018

ISSN: 2580-409X (Print) / 2549-6824 (Online)

Website: http://ojs.unpkediri.ac.id/index.php/intensif

ternyata yang paling prioritas adalah pembuatan karya ilmiyah, sedangkan untuk kriteria pengabdian masyarakat yang paling prioritas adalah pelatihan bagi masayarakat disekitar kampus karena dengan adanya pelatihan bagi masyarakat kampus dapat mensejahterakan pendidikan disekitar lingkungan kampus. Perbandingan antar setiap kriteria ditunjukkan pada gambar 7 sebagai berikut :

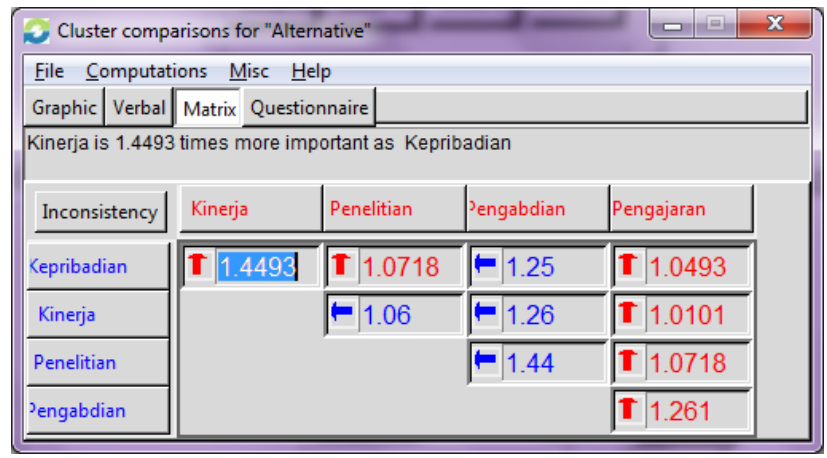

Gambar 7. PERBANDINGAN CLUSTER

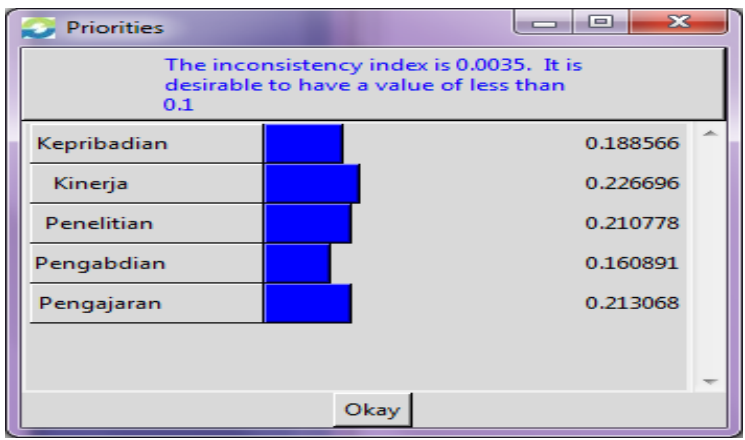

Gambar 8. PRIORITAS CLUSTER

Berdasarkan prioritas pada gambar 8 diatas maka didapatkan untuk persentase penilaian dosen berprestasiadalah sebagai berikut

Kinerja

$$
\begin{aligned}
& =22 \% \\
& =18 \% \\
& =21 \% \\
& =21 \% \\
& =16 \%
\end{aligned}
$$

Kepribadian

Pengajaran

Penelitian

Pengabdian masyrakat

Sedangkah hasil yang diperoleh dari semua alternatif yang berhak mendapatkan gelar dosen berprestasiadalah dosen A 
INTENSIF, Vol.2 No.2 August 2018

ISSN: 2580-409X (Print) / 2549-6824 (Online)

Website: http://ojs.unpkediri.ac.id/index.php/intensif

\begin{tabular}{|c|c|c|c|c|c|}
\hline \multicolumn{6}{|c|}{$\begin{array}{l}\text { Here are the overall synthesized priorities for the } \\
\text { alternatives. You synthesized from the network Super } \\
\text { Decisions Main Window: Db.mod: formulaic }\end{array}$} \\
\hline Name & Graphic & Ideals & Normals & Raw & \\
\hline Dosen A & & 1.000000 & 0.266714 & 0.120893 & \\
\hline Dosen B & & 0.926099 & 0.247004 & 0.111959 & \\
\hline Dosen C & & 0.908844 & 0.242402 & 0.109873 & \\
\hline Dosen D & & 0.914390 & 0.243881 & 0.110543 & \\
\hline Copy Values & & & & & - \\
\hline
\end{tabular}

Gambar 9. HASIL PERCOBAAN

Berdasarkan hasil pada gambar 9 menunjukkan bahwa dari data yang diolah dalam software super decision dengan menggunakan metode ANP dapat memberikan prediksi yang akurat dalam menentukan suatu keputusan dan hasil yang stabil. Jaringan pada metode ini memiliki kompleksitas yang lebih tinggi dengan jenis lain, karena adanya fenomena feedback dari cluster satu ke cluster lainnya bahkan dengan clusternya sendiri. Pada setiap kontrol yang ada dalam ANP tidak membutuhkan struktur hirarki seperti pada metode AHP

Berdasarkan data hasil perbandingan diatas maka dapat disimpulkan bahwa pemilihan dengan menggunakan ANP lebih akurat karena dengan menggunakan metode ANP dapat mengetahui tingkat kriteria yang berbeda, dan dengan menggunakan metode ANP setiap kriteria dan sub kriteria saling memiliki keterkaitan atau hubungan.

Berdasarkan penelitian tersebut maka lembaga dalam beberapa tahun kedepan dapat dengan mudah melakukan pengambilan keputusan dalam menentukan dosen berprestasi tanpa adanya pengkukuran kembali faktor yang paling prioritas, dengan begitu ANP dapat membantu lembaga untuk menilai dosen berprestasi berdasarkan kriteria-kriteria yang telah ditentukan persentasi yaitu Kinerja $=22 \%$, Kepribadian $=18 \%$, Pengajaran $=21 \%$, Penelitian $=21 \%$, Pengabdian masyarakat $=16 \%$

\section{KESIMPULAN DAN SARAN}

Dengan adanya sistem penunjang keputusan dalam menentukan kriteria-kriteria yang berkaitan dengan pemilihan dosen berprestasi maka lembaga dapat menentukan dosen berprestasi secara lebih tepat dan akurat. Berdasarkan penelitian diatas dapat dis impilkan bahwa faktor-faktor yang dapat mempengaruhi dalam menentukan dosen berprestasi adalah kinerja, kepribadian, pengajaran, penelitian dan pengabdian masyarakat. Dan yang memiliki tingkat prioritas tertinggi dalam menilai dosen berprestasi adalah kinerja. Berdasarkan hasil analisis 
INTENSIF, Vol.2 No.2 August 2018

ISSN: 2580-409X (Print) / 2549-6824 (Online)

Website: http://ojs.unpkediri.ac.id/index.php/intensif

data dari perbandingan setiap cluster maka didapatkan persentasenya adalah kinerja $=22 \%$, Kepribadian $=18 \%$, Pengajaran $=21 \%$, Penelitian $=21 \%$, Pengabdian masyarakat $=16 \%$. Metode ANP (Analytical Network Process) sangat bermanfaat dalam menentukan dosen berprestasi berdasarkan faktor-faktor yang telah ditentukan. Namun penelitian ini dapat dikembangkan dengan metode lain seperti TOPSIS, AHP, SMART dan lain-lain.

\section{DAFTAR PUSTAKA}

[1] I Ketut Putu Suniantara, Gede Suwardika , " Penerapan Metode VIKOR pada Pengambilan Keputusan Seleksi Calon Penerima Beasiswa Bidikmisi Universitas Terbuka" J Intensif, vol. 2 No. 1 Februari 2018.

[2] D. Andayati, "Sistem Pendukung Keputusan Pra-Seleksi Penerimaan Siswa Baru (PSB) On-Line Yogyakarta,” J. Teknol., vol. 3, no. 2, pp. 145-153, 2010.

[3] S. Eniyati and R. C. N. Santi, "Perancangan Sistem Pendukung Keputusan Penilaian Prestasi Dosen Berdasarkan Penelitian dan Pengabdian Masyarakat," J. Teknol. Inf. Din., vol. 15, no. 2, pp. 136-142, 2010.

[4] T. L. Saaty and L. G. Vargas, "The Analytic Network Process," pp. 1-40, 2013.

[5] L. W. Santoso, A. Setiawan, and J. R. Stanley, "Pembuatan Aplikasi Sistem Seleksi Calon Pegawai Dengan Metode Analytic Network Process (Anp) Di Pt X,” no. February 2015, 2011.

[6] DIKTI.2017. Pedoman Pemilihan Dosen Berprestasi. Kategori Sains Teknologi dan Sosial Humaniora

[7] Turban Efraim, Jay E. Aronson, Ting-Peng Liang "Decision Support Systems and Intelligent Systems”.p. 574. 2008.

[8] Neura Erika, dkk. "Analytic Network Process (ANP) : an Approach to Estimate the Colombian Baby Diapers Market share”. Colombia, 2009

[9] Setiawan, S., \& Rusdiansyah, R. (2016). PEMANFAATAN SISTEM PENDUKUNG KEPUTUSAN DALAM MENENTUKAN PROGRAM JAMINAN SOSIAL. Konferensi Nasional Ilmu Pengetahuan Dan Teknologi, 2(1), 7-INF.14. Retrieved from http://konferensi.nusamandiri.ac.id/prosiding/index.php/knit/article/view/39

[10] Nalsa Cintya Resti, "Penerapan Metode Simple Additive Weighting (SAW) pada Sistem Pendukung Keputusan Pemilihan Lokasi untuk Cabang Baru Toko Pakan UD. Indo Multi Fish”, J Intensif, vol. 1 No. 2 Agustus 2017. 